\title{
Yanhusuo extract inhibits metastasis of breast cancer cells by modulating mitogen-activated protein kinase signaling pathways
}

\author{
JIAN-LI GAO ${ }^{1}$, JUN-MIN SHI ${ }^{1}$, KAI HE ${ }^{2}$, QING-WEN ZHANG ${ }^{1}$, \\ SHAO-PING LI ${ }^{1}$, SIMON MING-YUEN LEE ${ }^{1}$ and YI-TAO WANG ${ }^{1}$ \\ ${ }^{1}$ Institute of Chinese Medical Sciences, University of Macau, Macau 999078; ${ }^{2}$ The First Affiliated \\ Hospital, College of Medicine, Zhejiang University, Hangzhou, Zhejiang 310003, P.R. China
}

Received April 2, 2008; Accepted May 22, 2008

DOI: 10.3892/or_00000079

\begin{abstract}
Yanhusuo (Corydalis yanhusuo W.T. Wang) is a well-known traditional Chinese medicine (TCM). In this study, we attempted to characterize in detail the signaling cascades that produce its anti-metastatic effect on the human breast cancer cell line, MDA-MB-231. We found that the yanhusuo extract inhibited the migration and invasion of MDA-MB-231 cells in vitro. In addition, the yanhusuo extract inhibited the mRNA expression and activity of metalloproteinase-9 (MMP-9). The anti-cancer metastasis effect of yanhusuo involved the activation of $\mathrm{p} 38$ and inhibition of ERK1/2 and SAPK/JNK mitogen-activated protein kinase (MAPK) signaling. Our experiments identified the biological activity of yanhusuo against cancer metastasis in vitro and provide a rationale for its further investigation.
\end{abstract}

\section{Introduction}

Tumor metastasis causes $90 \%$ of deaths from solid tumors and produces a remarkably diverse set of clinical manifestations. One of the challenges for researchers is the development of new metastasis inhibitors. Many studies have demonstrated that some traditional Chinese medicines (TCM) or compounds isolated and purified from TCMs have potential anti-metastatic activity (1-4), including Ganoderma lucidum, silibinin (from Silybum marianum L.), luteolin (from many kinds of herbs and vegetables) and emodin (from Rheum palmatum).

Yanhusuo (Corydalis yanhusuo W.T. Wang; YHS) is a well-known 'Huoxue Zhitong' TCM used to invigorate blood and is commonly prescribed as a painkiller for patients with

Correspondence to: Dr Simon Ming-Yuen Lee or Professor Yi-Tao Wang, Institute of Chinese Medical Sciences, University of Macau, Av. Padre Toma's Pereira S.J., Taipa, Macao 999078, P.R. China E-mail: simonlee@umac.mo or ytwang@umac.mo

Key words: breast cancer, Corydalis yanhusuo, cell invasion, mitogen-activated protein kinase, metalloproteinases terminal cancer for thousands of years in China. In TCM, YHS is commonly used to dispel stasis and move $q i$, reinforce vital energy and alleviates painful conditions such as headache, chest pain, epigastric pain, abdominal pain and backache (5).

The main active constituents isolated from YHS are alkaloids (6) and several studies have shown that these possess potential anti-tumor activity, including anti-metastatic activity. For example, dl-tetrahydropalmatine ( $d l$-THP) depresses LPS-induced overexpression of ICAM-1 and Eselectin in human umbilical vein endothelium cells (7); $d l$-THP interacts with P-gp and alters its ATPase activity to reverse multidrug resistance (MDR) and enhances the ability of vincristine to inhibit the proliferation of human leukemia cell lines (8); berberine has anti-proliferative effects on U937 and B16 cells in vitro and anti-metastatic effects in non-small lung cancer (9-11); palmatine and its analogs have selective cytotoxicity against SF-268 and RPMI-8402 cells (12); glaucine and boldine not only possess anti-oxidant activity but also have anti-tumor potential by inhibiting TPA (phorbol 12-myristate 13-acetate, PMA)-induced downregulation of gap junctional intercellular communication (13); and YhPS-1 (a polysaccharide isolated from the root of C. yanhusuo) inhibits the growth of Sarcoma 180 and Lewis pulmonary carcinoma implanted in mice (14).

There are, therefore, several lines of evidence indicating that alkaloids, the main components of YHS, have anti-tumor growth activities in vivo, direct cytotoxic effects on cancer cells, anti-drug resistance effects and anti-metastatic activity both in vitro and in vivo. Its anti-metastatic activity may explain its traditional use in cancer patients, though few studies have specifically focused on this characteristic. We studied the effects of YHS on MDA-MB-231 cancer cell migration and invasion, as well as the role of phosphorylation of the MAPK pathway in the anti-metastatic effect.

Our findings show that an ethanol extract of YHS is a strong suppressor for cancer metastasis. We further demonstrated that YHS effectively suppresses the extracellular signal-regulated kinase 1/2 (ERK1/2) and stress-activated protein kinase/c-Jun NH2-terminal kinase (SAPK/JNK) signaling pathways, leading to decreased MMP-9 mRNA expression and activity. 


\section{Materials and methods}

Reagents and materials. RPMI-1640 (Roswell Park Memorial Institute), fetal bovine serum (FBS), phosphate-buffered saline (PBS), penicillin-streptomycin (PS) and $0.25 \%(\mathrm{w} / \mathrm{v})$ trypsin/ $1 \mathrm{mM}$ EDTA were purchased from Invitrogen (Carlsbad, CA, USA). Antibodies against JNK, ERK1/2, p38, phospho-JNK, phospho-ERK1/2 and phospho-p38 were obtained from Cell Signaling (Danvers, MA, USA). TPA (tetradecanoylphorbol-1, 3-acetate) and DMSO (dimethyl sulfoxide) were purchased from Sigma (St Louis, MO). The C. yanhusuo was purchased from the Huadong Medicine Group Co., Ltd (Hangzhou, Zhejiang, P.R. China).

Cell lines and culture. MDA-MB-231 cells (human breast cancer cell line) were purchased from ATCC (Manassas, VA, USA). MDA-MB-231 cells were cultured in a monolayer at $37^{\circ} \mathrm{C}$ and $5 \% \mathrm{CO}_{2}$ in RPMI-1640 medium supplemented with $10 \%$ fetal bovine serum (FBS), $100 \mathrm{mg} / \mathrm{ml}$ streptomycin and $100 \mathrm{U} / \mathrm{ml}$ penicillin.

Sample preparation and analysis. The rhizome of Corydalis yanhusuo was cut into small pieces, ground into a fine powder, and extracted by $95 \%$ alcohol five times. After retrieving the alcohol, the extract was freeze dried, producing a powdery, crude YHS extract of $1.85 \%(\mathrm{w} / \mathrm{w})$. High performance liquid chromatography (HPLC; Fig. 1) showed that the dehydrocorydaline, berberine and palmatine contents were, respectively, $2.925,0.75$ and $0.275 \%$. Stock solutions of the YHS extract of $100,30,10$ and $3 \mathrm{mg} / \mathrm{ml}$ were prepared in DMSO.

Assessment of cell viability. The effect of YHS extract on cell viability was estimated with the MTT [3-(4, 5-dimethyl-2thiazolyl)-2, 5-diphenyl tetrazolium bromide] assay (15). MDA-MB-231 cells were seeded at $2 \times 10^{4}$ cells/well density in 96-well plates and incubated with different concentrations of the YHS extract for $48 \mathrm{~h}$. Cell growth was monitored by the classic MTT assay. Briefly, $30 \mu 1$ of MTT reagent $(5 \mathrm{mg} / \mathrm{ml}$ in PBS) (USB, OH, USA) was added to each well. After $4 \mathrm{~h}$ at $37^{\circ} \mathrm{C}$, the cell supernatants were discarded, MTT crystals were dissolved in $100 \mu 1 \mathrm{DMSO}$ and absorbance was measured at $570 \mathrm{~nm}$ using a Multilabel counter (Perkin Elmer, 1420 Multilabel Counter Victor3, Wellesley, USA). All assays were performed in triplicate. The relative growth rate was defined as the percentage of absorbance of the treated cells compared to that of the untreated cells.

Two-dimensional cell migration assay. A two-dimensional cell migration assay using a wound-healing model was performed, as previously described (16). The cells were seeded into each well of a 24-well plate and incubated with a complete medium at $37^{\circ} \mathrm{C}$ and $5 \% \mathrm{CO}_{2}$. Upon $24 \mathrm{~h}$ of incubation, the cells were starved overnight by a serum-free medium. The cells were then scraped away horizontally in each well using a $200 \mu 1$ yellow pipette tip. Three randomly selected views along the scrapped line were photographed on each well at x 50 magnification using an Axiovert 200 fluorescent inverted microscope (Carl Zeiss, HK) and an AxioCam HRC CCD camera (Carl Zeiss) as soon as the medium was changed to a serum-free medium containing different concentrations of the YHS extract. After $24 \mathrm{~h}$ of incubation, a set of images was taken and analyzed using the Metamorph Imaging Series. The average scrapped width of each well was measured and deducted from that taken before YHS was added.

Three-dimensional cell migration assay. A three-dimensional cell migration assay was performed with the Transwell system, which allows cells to migrate through an $8 \mu \mathrm{m}$ pore size polycarbonate membrane. MDA-MB-231 cells were trypsinized, washed and re-suspended in serum-free RPMI$1640\left(2.5 \times 10^{5}\right.$ cells/ml $)$. RPMI-1640 medium (500 $\left.\mu 1\right)$ (containing 1\% FBS and different concentrations of YHS extracts) was added to the 24-well plate (the lower chamber of the Transwell) and $200 \mu 1$ of cell suspension (containing corresponding concentrations of YHS extracts) was added to the upper chamber. After incubation for $12 \mathrm{~h}$ at $37^{\circ} \mathrm{C}$, the non-migrating cells were carefully removed from the upper surface of the insert with a wet cotton swab. The migrated cells were fixed overnight in $3.7 \%$ formaldehyde at $4^{\circ} \mathrm{C}$ and stained with Hoechst 33258 in PBS (1:1000) for $15 \mathrm{~min}$. The filters were then rinsed thoroughly in PBS and mounted on glass slides. To quantify cell motility, cells that had migrated to the bottom surface of the filter were counted. Three evenly-spaced fields of cells were counted in each well at x100 magnification using Axiovert 200 fluorescent inverted microscope (Carl Zeiss) and AxioCam HRC CCD camera (Carl Zeiss). The images were counted with Metamorph Imaging Series software (Molecular Devices, Tokyo, Japan). All assays were performed in triplicate.

Cell invasion assay. Cell invasion assay was carried out using the same method as a three-dimensional cell migration assay with a slight modification in that both sides of the insert were pre-coated with Matrigel. Briefly, different amounts of Matrigel (40 $\mu \mathrm{g}$ for the upper side and $32 \mu \mathrm{g}$ for the lower side) were coated on the chambers for $6 \mathrm{~h}$ at $37^{\circ} \mathrm{C}$. MDAMB-231 cells were suspended in serum-free RPMI-1640 $\left(2.5 \times 10^{5}\right.$ cells $\left./ \mathrm{ml}\right)$. RPMI-1640 medium $(500 \mu \mathrm{l})$ (containing $1 \%$ FBS and different concentrations of YHS extracts) was added to the lower chamber and $200 \mu 1$ of cell suspension (containing corresponding concentrations of YHS extracts) was added to the upper chamber. The plate was incubated for $12 \mathrm{~h}$ at $37^{\circ} \mathrm{C}$ in the presence of $5 \% \mathrm{CO}_{2}$.

Western blotting. SDS-PAGE and Western blotting were performed to evaluate the protein expression levels of JNK, ERK1/2, p38, phospho-JNK, phospho-ERK1/2 and phosphop38. Briefly, cells were treated as designated in $1 \%$ FBS RPMI-1640 for $2 \mathrm{~h}$. Cell pellets were lysed in RIPA lysis buffer (Santa Cruz, CA) with 1\% PMSF, $1 \%$ protease inhibitor cocktail and $1 \%$ sodium orthovanadate. After treatment on ice for $30 \mathrm{~min}$, cell lysates were clarified by centrifugation at $11,419 \times \mathrm{g}$ for $20 \mathrm{~min}$ at $4^{\circ} \mathrm{C}$ to remove cell debris and the protein content was measured using a BCA protein assay kit (Pierce, Rockford, IL). Aliquots of the lysates were subjected to $10 \%$ SDS-PAGE (with $6 \%$ stacking gel) and transferred to a PVDF membrane (Bio-Rad, Hercules, CA). The membrane was probed with a primary antibody (1:1000) followed by a second antibody and visualized using an ECL advanced 


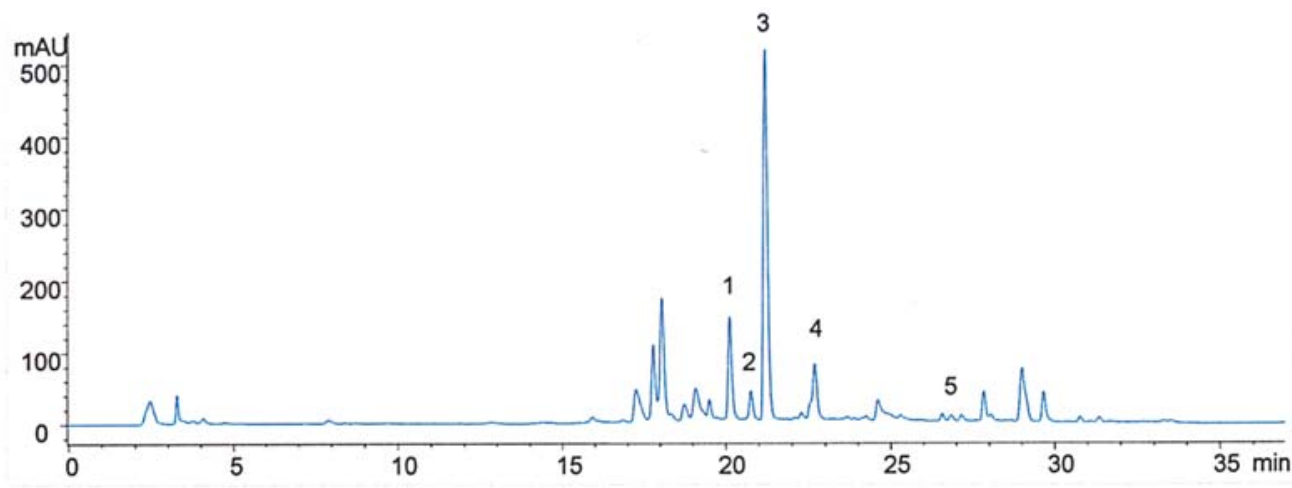

Figure 1. HPLC chromatogram of the ethanol extract of Corydalis yanhusuo W.T. Wang. 1, palmatine; 2, berberine; 3, dehydrocorydaline; 4 , tetrahydroberberine and 5, tetrahydropalmatine. HPLC condition: The HPLC column was an Agilent SB C18 column $(250 \times 4.6 \mathrm{~mm}$, id $=5 \mu \mathrm{m})$. We used Milli-Q water (containing $0.2 \%$ acetic acid and triethylamine) ( $\mathrm{pH}$ 5.0) and acetonitrile as the mobile phase. The DAD detection wavelength was set at 254 $\mathrm{nm}$.

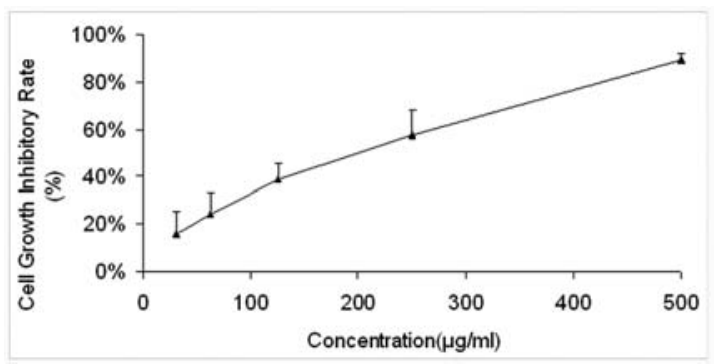

Figure 2. Effects of the YHS extract on the proliferation of MDA-MB-231 cells $(n=24)$. Cells $(20,000$ cells/well $)$ were exposed to the indicated concentrations of the YHS extract $(0-500 \mu \mathrm{g} / \mathrm{ml})$ for $48 \mathrm{~h}$ and cell viability was determined using MTT assay. Values represent the means \pm S.D. obtained from three independent experiments.

Western blotting detection kit (Amersham, UK) according to the manufacturer's protocol. Densitometric measurements of band intensity in the Western blots were performed using Quantity One Software (provided by Bio-Rad).

Gelatin zymography. Gelatin zymography was performed using $7.5 \%$ polyacrylamide gels containing $0.1 \%$ gelatin. Cells were treated with 3,10 and $30 \mu \mathrm{g} / \mathrm{ml}$ YHS extract in $1 \%$ FBS RPMI-1640 (containing $20 \mathrm{ng} / \mathrm{ml}$ TPA) for $48 \mathrm{~h}$. The cell culture medium was centrifuged at $350 \mathrm{x} \mathrm{g}$ for $4 \mathrm{~min}$ at $4^{\circ} \mathrm{C}$. The supernatant medium $(40 \mu \mathrm{l})$ and cell lysates (extracted with RIPA lysis buffer) were mixed with $10 \mu \mathrm{l}$ of $5 \mathrm{X}$ nonreducing sample buffer [62.5 mM Tris- $\mathrm{HCl}, \mathrm{pH} 6.8,2 \%$ SDS, $25 \%$ (v/v) glycerol, $0.01 \%$ bromophenol blue]. Mixed sample (25 $\mu \mathrm{l}$ ) was loaded in 10-well gels and electrophoresis was performed at $100 \mathrm{~V}$ for $1.25 \mathrm{~h}$. After electrophoresis, the gels were rinsed with $1 \mathrm{X}$ renaturing buffer for $1.5 \mathrm{~h}$ at room temperature. The buffer was then switched to $1 \mathrm{X}$ developing buffer and the gels were incubated for $48 \mathrm{~h}$ at $37^{\circ} \mathrm{C}$. The gels were stained with Coomassie blue and then de-stained with $10 \%$ acetic acid. The unstained bands corresponded to the areas of gelatin digestion.

RNA isolation and real-time PCR analysis. The total RNA of the MDA-MB-231 cells was extracted using ABI PRISM ${ }^{\circledR}$ 6100 Nucleic Acid PrepStation according to the manufacturer's instructions. The quantity of RNA was measured by spectro-
2D-migration

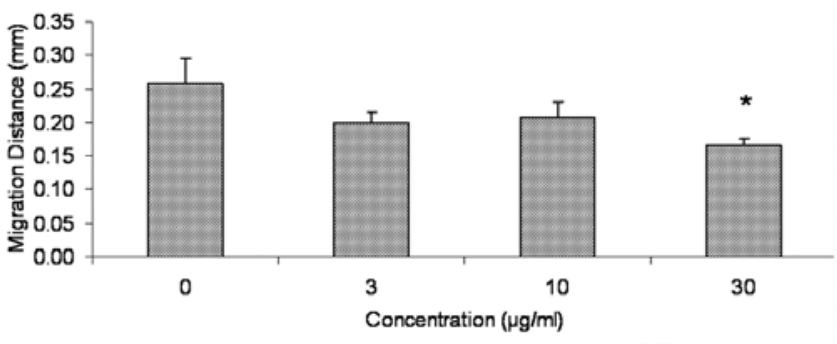

3D-migration

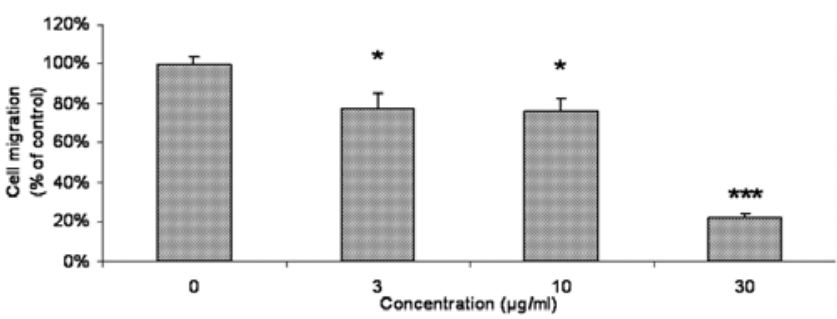

Figure 3. Effects of the YHS extract on the migration of MDA-MB-231 cells $(n=9)$. 2D-migration: Confluent monolayers of MDA-MB-231 cells were scraped away horizontally using a pipette tip. Wound closure was monitored microscopically after treatment with different concentrations of the YHS extract for $24 \mathrm{~h}$. 3D-migration: Cells $\left(5 \times 10^{4} /\right.$ well $)$ were seeded onto the upper chamber of Transwell plates and treated with the YHS extract for $12 \mathrm{~h}$. The lower surfaces of the membranes from the Transwell units were fixed and stained. Cells that had invaded the lower surface of the membranes were counted. Values represent the means \pm S.E.M. obtained from three independent experiments $(\mathrm{n}=9) .{ }^{* * *} \mathrm{P}<0.001$ vs. vehicle control; ${ }^{* *} \mathrm{P}<0.01$ vs. vehicle control and ${ }^{*} \mathrm{P}<0.05$ vs. vehicle control.

photometric analysis at $260 \mathrm{~nm}$ (Beckman Coulter DU ${ }^{\circledR} 640$, Fullertion, CA, USA). The quality and integrity of the extracted RNA was assessed by spectrophotometric analysis at $260 / 280 \mathrm{~nm}$ and gel electrophoresis in $1.0 \%$ agarose trisacetate-EDTA (TAE) gels and visualized by ethidium bromide staining under ultraviolet (UV) light. Total RNA (1 $\mu \mathrm{g})$ was converted to single-strand cDNA using SuperScript ${ }^{\mathrm{TM}}$ III First-Strand Synthesis System for RT-PCR (Invitrogen ${ }^{\mathrm{TM}}$ ). Each $\mathrm{RT}$-PCR reaction consisted of denaturation at $65^{\circ} \mathrm{C}$ for $5 \mathrm{~min}$, annealing at $25^{\circ} \mathrm{C}$ for $10 \mathrm{~min}$, cDNA synthesis at $50^{\circ} \mathrm{C}$ for $50 \mathrm{~min}$, termination of reaction at $85^{\circ} \mathrm{C}$ for $5 \mathrm{~min}$ and removal of RNA by RNase $\mathrm{H}$ at $37^{\circ} \mathrm{C}$ for 

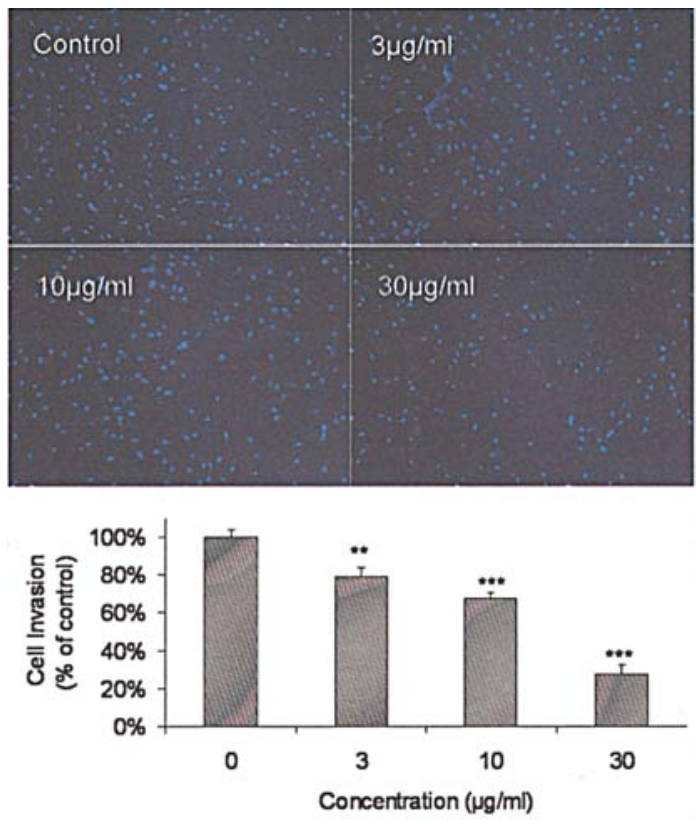

Figure 4. Effects of the YHS extract on the invasion of MDA-MB-231 cells $(n=9)$. Cells $\left(5 \times 10^{4} /\right.$ well) were seeded onto the Matrigel coated upper chamber of Transwell plates and then treated with the YHS extract for $12 \mathrm{~h}$. The lower surfaces of the membranes from the Transwell units were fixed and stained. Cells that had invaded the lower surface of the membranes were counted. Values represent the means \pm S.E.M. obtained from three independent experiments $(\mathrm{n}=9) .{ }^{* * *} \mathrm{P}<0.001 \mathrm{vs}$. vehicle control; ${ }^{* *} \mathrm{P}<0.01$ vs. vehicle control and ${ }^{*} \mathrm{P}<0.05$ vs. vehicle control.

20 min, using the Gene Amp ${ }^{\circledR}$ PCR System 9700 (Applied Biosystems, Singapore).

Taq Man ${ }^{\circledR}$ probes and primers for MMP-9 and $\beta$-actin were purchased from Applied Biosystems (Foster City, CA, USA). The RT-PCR product derived from $0.06 \mu \mathrm{g}$ RNA was used in a $20 \mu \mathrm{l}$ PCR reaction containing $10 \mu \mathrm{l} 2 \mathrm{x}$ PCR Master Mix (Taq Man Universal PCR Master Mix, Branchburg, NJ, USA) and $250 \mathrm{nM}$ each of primers. The PCR was performed in the ABI 7500 real-time PCR system (Applied Biosystems) with the amplification profile, as previously described. A reaction without the RT-PCR product served as a negative control. The relative expression levels of MMP-9 mRNA were normalized to the amount of $\beta$-actin in the same cDNA using the relative quantification method.

Statistical analysis. Migration and proliferation assay results were converted to indices by normalizing each value as a

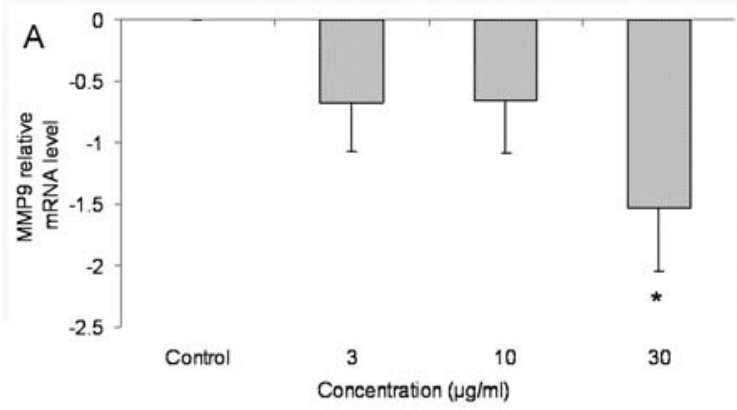

B

TPA

YHS extract $(\mu \mathrm{g} / \mathrm{ml})$

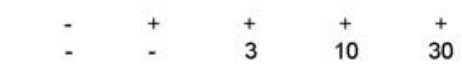

Cell culture medium

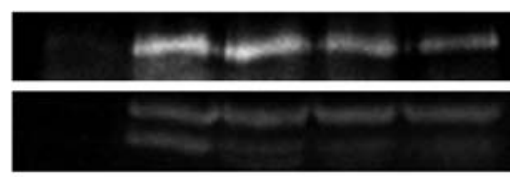

Figure 5. Effect of the YHS extract on TPA-induced enzymatic activity and mRNA expression of MMP-9. (A) Decrease in TPA-induced MMP-9 gene expression after YHS treatment; values represent the means \pm S.E.M. obtained from three independent experiments $(n=3)$. ${ }^{*} \mathrm{P}<0.05$ vs. vehicle control. (B) Cells were incubated with $20 \mathrm{ng} / \mathrm{ml}$ TPA and different concentrations of the YHS extract for $48 \mathrm{~h}$. Conditioned media and cells were harvested for gelatin zymography.

percent of the control. Significant results were determined using the Student's t-test and were accepted when $\mathrm{p}$-values were $<0.05$.

\section{Results}

YHS extract inhibits the proliferation of MDA-MB-231 cells. Under the experimental conditions, the YHS extract exhibited a significant growth inhibitory effect on MDA-MB-231 cells. The $\mathrm{IC}_{50}$ was $\sim 220 \mu \mathrm{g} / \mathrm{ml}$. Cell growth was suppressed by the YHS extract in a dose-dependent manner (Fig. 2).

Effect of YHS extract on migration of MDA-MB-231 cells. Treatment with 3,10 and $30 \mu \mathrm{g} / \mathrm{ml}$ of the YHS extracts reduced the migration of MDA-MB-231 breast cancer cells to $63.5,80.1$ and $77.1 \%$, respectively, in the wound-healing model, compared to the vehicle control (Fig. 3). After treatment with 3,10 and $30 \mu \mathrm{g} / \mathrm{ml}$ of the YHS extract in the 3D-migration assay, the migration of MDA-MB-231 cells
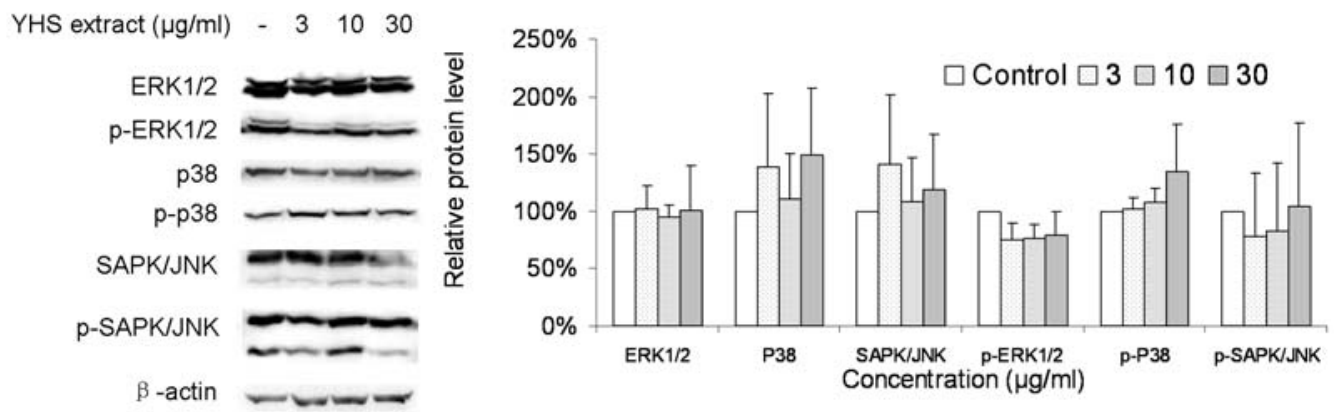

Figure 6. Effect of the YHS extract on the phosphorylation of ERK, JNK and p38 MAPKs. Cells were pretreated with 3 , 10 , or $30 \mu \mathrm{g} / \mathrm{ml}$ of the YHS extract for $2 \mathrm{~h}$. Western blotting of whole cell lysates was performed, as described previously. 
was reduced to $77.5,76.1$ and $22.4 \%$, respectively, compared to the control (Fig. 3). In particular, $30 \mu \mathrm{g} / \mathrm{ml}$ of YHS significantly inhibited cancer cell migration $(\mathrm{p}<0.001)$.

In short, the YHS extract inhibited two- and threedimensional migration (chemotactic response) of the breast cancer cells in a dose-dependent manner. This suggests that YHS has a suppressive effect on MDA-MB-231 breast cancer cell migration in non-cytotoxic concentrations.

YHS extract suppresses invasion of MDA-MB-231 cells. The extract of YHS produced a significant, dose-dependent inhibition of MDA-MB-231 cell invasion on Matrigel (Fig. 4). The ability of cells to invade was reduced to 79.2, 67.7 and $27.7 \%$ after treatment with the YHS extract at concentrations of 3,10 and $30 \mu \mathrm{g} / \mathrm{ml}$, respectively.

YHS extract decreases MMP-9 mRNA expression and enzymatic activity in TPA-activated MDA-MB-231 cells. TPA (tetradecanoylphorbol-1, 3-acetate) stimulated both MMP-9 mRNA expression and enzymatic activity in MDAMB-231 cells. The effects of the YHS extract on MMP-9 mRNA expression in TPA-activated MDA-MB-231 cells were examined by RT-PCR. The cells treated with the YHS extract for $24 \mathrm{~h}$ showed a reduced expression of MMP-9 at the mRNA level (Fig. 5A). In addition, the activity of MMP-9 and the secretion of pro-MMP-2 in TPA-activated MDA-MB231 cells was significantly reduced when the MDA-MB-231 cells were treated with 10 or $30 \mu \mathrm{g} / \mathrm{ml}$ of the YHS extract (Fig. 5B).

Suppressive effect of YHS on phosphorylation of ERK1/2 and $S A P K / J N K$. Previous research suggests that MAPK signaling pathways may help regulate the expression and activation of MMP-9 in breast carcinomas $(17,18)$. To determine the effect of YHS on ERK activation in MDA-MB-231, cells were cultured at different concentrations of the YHS extracts for $2 \mathrm{~h}$. As expected, treatment with $10 \mu \mathrm{g} / \mathrm{ml}$ of the YHS extract reduced the phosphorylation of ERK1/2 and SAPK/JNK to 76.5 and $83.1 \%$ respectively, compared to the control (Fig. 6). The induction of phosphorylation of p38 MAPK in the YHS extract-treated cells was observed (Fig. 6). The relative protein levels of phospho-p38 were 101.5, 107.2 and 134.7\%, after treatment with 3,10 and $30 \mu \mathrm{g} / \mathrm{ml}$ YHS extracts, respectively.

\section{Discussion}

Many compounds in YHS have inhibitory effects on cancer cell proliferation (19) and anti-metastatic effects on non-small lung cancer $(10,11)$. However, the mechanism of the antimetastatic effect is unclear. We investigated the potential of YHS in reducing cancer cell invasion and the mechanisms involved in this.

Proteolysis of ECMs (Extracellular Matrices), especially the basement membranes, is a key event during tumor invasion. Matrix metalloproteinases (MMPs), which can degrade all ECM components, play a pivotal role in matrix degradation during tumor growth and invasion, and tumorinduced angiogenesis. Among the MMPs, MMP-9 is thought to play a critical role during tumor invasion and metastasis and is functionally involved in the progression of invasiveness of breast cancer cells. We investigated the influence of YHS on the TPA (tetradecanoylphorbol-1, 3-acetate)-induced gene expression of MMP-9 and the in vitro invasiveness of human breast cancer cells.

We found that TPA produced increased MMP-9 in the MDA-MB-231 cell line, though non-cytotoxic doses of the YHS ethanol extract efficiently suppressed the invasiveness of TPA-treated cancer cells (Fig. 4) by decreasing the activity and synthesis of the MMP-9 protein (Fig. 5). Our results indicate that treatment with the YHS extract for 24 or $48 \mathrm{~h}$ decreased mRNA expression and gelatinase activity of MMP-9 in a dose-dependent manner (Fig. 5).

It is well known that MMP-9 mRNA expression is mediated by MAPK pathways. MAPK/ERK (20) and MAPK/p38 (21) pathways are involved in the regulation of MMP-9 mRNA expression in cancer cells. To demonstrate the mechanism by which the YHS extract suppresses cancer cell metastasis, we looked at the phosphorylation of ERK1/2, p38 and SAPK/JNK in breast cancer cells after treatment with the YHS extract. YHS suppressed the phosphorylation of ERK1/2 and SAPK/JNK MAPKs, although it increased the phosphorylation of p38 MAPK. These results suggest that all of the MAPK/ERK, MAPK/p38 and SAPK/JNK pathways may be involved in TPA-induced up-regulation of MMP-9 in breast carcinomas and that the YHS ethanol extract could efficiently suppress the activity and synthesis of MMP-9 through the MAPK signaling pathways.

In conclusion, we demonstrated that the YHS extract inhibits breast cancer cell migration and invasion by suppressing the ERK1/2 and SAPK/JNK signaling pathways. The inhibitory effects of YHS on growth and its disruption of MAPK signal transduction may contribute to an overall antimetastatic effect. YHS may be of therapeutic value in preventing invasion or metastasis of human cancers. However, further investigations are needed to identify the precise mechanisms by which YHS inhibits cancer metastasis.

\section{Acknowledgements}

This study was supported by the Macao Science and Technology Development Fund (049/2005/A-R1) and the University of Macau (RG075/06-07S/WYT/ICMS).

\section{References}

1. Wu QP, Xie YZ, Li SZ, La Pierre DP, Deng ZQ, Chen Q, Li C, Zhang Z, Guo J, Wong CK, Lee DY, Yee A and Yang BB: Tumour cell adhesion and integrin expression affected by Ganoderma lucidum. Enzyme Microb Technol 40: 32-41, 2006.

2. Lee SO, Jeong YJ, Im HG, Kim CH, Chang YC and Lee IS: Silibinin suppresses PMA-induced MMP-9 expression by blocking the AP-1 activation via MAPK signaling pathways in MCF-7 human breast carcinoma cells. Biochem Biophys Res Commun 354: 165-171, 2007.

3. Lee WJ, Wu LF, Chen WK, Wang CJ and Tseng TH: Inhibitory effect of luteolin on hepatocyte growth factor/scatter factorinduced HepG2 cell invasion involving both MAPK/ERKs and PI3K-Akt pathways. Chem Biol Interact 160: 123-133, 2006.

4. Huang Q, Shen HM and Ong CN: Inhibitory effect of emodin on tumor invasion through suppression of activator protein-1 and nuclear factor-кB. Biochem Pharmacol 68: 361-371, 2004.

5. Chinese Pharmacopoeia Commission (ed.) Pharmacopoeia of the People's Republic of China. Chemical Industry Press, Beijing, p94, 2005. 
6. He K, Gao JL and Zhao GS: Advances in studies on chemistry, pharmacology and quality control of Corydalis YHS. Zhong Cao Yao 38: 11-14, 2007.

7. Zhang ZM, Jiang B and Zheng XX: Effect of 1-tetrahydropalmatine on expression of adhesion molecules induced by lipopolysaccharides in human umbilical vein endothelium cell. Chin J Chinese Materia Medica 30: 861-864, 2004.

8. He L and Liu GQ: Interaction of multidrug resistance reversal agents with P-glycoprotein ATPase activity on blood-brain barrier. Acta Pharmacol Sin 23: 423-429, 2002.

9. Letasiová S, Jantová S, Cipák L and Múcková M: Berberineantiproliferative activity in vitro and induction of apoptosis/ necrosis of the U937 and B16 cells. Cancer Lett 239: 254-262, 2006.

10. Peng PL, Hsieh YS, Wang CJ, Hsu JL and Chou FP: Inhibitory effect of berberine on the invasion of human lung cancer cells via decreased productions of urokinase-plasminogen activator and matrix metalloproteinase-2. Toxicol Appl Pharmacol 214: 8-15, 2006.

11. Wu HL, Hsu CY, Liu WH and Yung YM: Berberine-induced apoptosis of human leukemia HL-60 cells is associated with down-regulation of nucleophosmin/B23 and telomerase activity. Int J Cancer 81: 923-929, 1999.

12. Sanders MM, Liu A, Li TK, Wu HY, Desai SD, Mao Y, Rubin EH, LaVoie EJ, Makhey D and Liu LF: Selective cytotoxicity of topoisomerase-directed protoberberines against glioblastoma cells. Biochem Pharmacol 56: 1157-1166, 1998.

13. Hu J, Speisky W and Cotgreave IA: The inhibitory effects of boldine, glaucine, and probucol on TPA-induced down regulation of gap junction function. Biochem Pharmacol 50: 1635-1643, 1995.

14. Tao YW and Tian GY: Studies on the physicochemical properties, structure and antitumor activity of polysaccharide YhPS-1 from the root of Corydalis yanhusuo Wang. Chin J Chem 24: 235-239, 2006.
15. Sa F, Gao JL, Fung KP, Zheng Y, Lee MY and Wang YT: Antiproliferative and pro-apoptotic effect of Smilax glabra Roxb. extract on hepatoma cell lines. Chem Biol Interact 171: 1-14, 2008.

16. Lam HW, Lin HC, Lao SC, Gao JL, Hong SJ, Yue YK, Kwan YW, Leong CW, Leung YH, Lee MY and Wang YT: The angiogenic effects of Angelica sinensis extract on HUVEC in vitro and zebrafish in vivo. J Cell Biochem 103: 195-211, 2008.

17. Bartsch JE, Staren ED and Appert HE: Matrix metalloproteinase expression in breast cancer. J Surg Res 110: 383-392, 2003.

18. Kaneshiro T, Morioka T, Inamine M, Kinjo T, Arakaki J, Chiba I, Sunagawa N, Suzui M and Yoshimi N: Anthraquinone derivative emodin inhibits tumor-associated angiogenesis through inhibition of extracellular signal-regulated kinase $1 / 2$ phosphorylation. Eur J Pharmacol 553: 46-53, 2006.

19. Mitani N, Murakami K, Yamaura T, Ikeda T and Saiki I: Inhibitory effect of berberine on the mediastinal lymph node metastasis produced by orthotopic implantation of Lewis lung carcinoma. Cancer Lett 165: 35-42, 2001.

20. Reddy KB, Krueger JS, Kondapaka SB and Diglio CA: Mitogen-activated protein kinase (MAPK) regulates the expression of progelatinase B (MMP-9) in breast epithelial cells. Int J Cancer 82: 268-273, 1999.

21. Simon C, Simon M, Vucelic G, Hicks MJ, Plinkert PK, Koitschev A and Zenner HP: The p38 SAPK pathway regulates the expression of the MMP-9 collagenase via AP-1-dependent promotor activation. Exp Cell Res 271: 344-355, 2001. 